\title{
Light Level Influences Spur Quality and Canopy Development and Light Interception Influence Fruit Production in Apple
}

\author{
Bruce H. Barritt, Curt R. Rom,'Bonnie J. Konishi, and Marc A. Dilley \\ Washington State University, Tree Fruit Research and Extension Center, Wenatchee, WA 98801
}

To model canopy growth and fruiting of apple trees, a thorough understanding of the interaction of light levels and leaf and fruit growth is required. Light distribution within a tree canopy is determined by spatial aspects of leaf development, which is usually influenced by horticultural practices such as pruning and tree training. However, individual leaf growth is itself directly influenced by light penetration to the site of leaf development. In this paper we discuss the influence of light levels on the development of individual vegetative and fruiting spurs of apple and the relationships of light interception, leaf development, and fruit production for whole trees.

Apple tree canopy development within a season and over the life of an orchard is crucial to the production of high quality fruit each season and to the early and sustained productivity of the orchard. Canopy development within a season and, in many cases, its development the following season can be influenced by cropping level, mineral nutrition, moisture level, plant growth regulators, pruning and training, scoring, light distribution, rootstock, and cultivar. The effect of these factors on canopy development was recently reviewed by Forshey and Elfving (1989). However, few studies have examined the influence of these factors on the development of individual spurs, the site of fruiting on apple trees.

Spur leaves develop before shoot leaves (Cain, 1973; Forshey et al., 1987; Lakso, 1984). When spur leaf area is reduced, fruit set, fruit size, and fruit Ca level are also reduced (Abbott, 1960; Ferree and Palmer, 1982; Rom and Ferree, 1984a). A greater than 2-fold difference in leaf area per spur at bloom (Rom and Ferree, 1984c) and during midsummer (Barritt and Schonberg, 1990; Oh et al., 1987) has been found among cultivars. Canopy position and light levels strongly influence leaf area per spur at full canopy (Barritt et al., 1987; Ferree, 1989; Ferree and Forshey, 1988). Spur leaf area has been increased and decreased with growth regulators (Curry and Williams, 1983; Ferree and Schmid, 1988). Unpruned trees have greater total spur leaf area and less shoot leaf area than pruned trees (Lakso, 1984). Fruiting spurs have smaller leaves and less leaf area per spur than vegetative spurs (Barritt et al., 1987; Lakso, 1984).

Horticulturists generally believe that the key to high early production in high density orchard systems is the rapid development of leaf canopy in the first few years after planting. High leaf area early in the life of the orchard is achieved by planting at high tree densities, by planting large, well-branched (feathered) trees, and by minimal pruning. Few studies have examined the relationships of leaf area/ha (orchard leaf area index), light interception, and yield with diverse apple orchard systems. With apple, light interception has been associated with leaf area/ha (Barritt, 1989; Jackson and Palmer, 1974; Palmer and Jackson, 1977) and with yield/ha (Barritt, 1989; Jackson, 1978; Jackson and Palmer, 1974; Robinson and Lakso, 1989; Wagenmakers and Callesen, 1989; Wertheim et al., 1986). The objectives of the studies reported here are to 1) describe the seasonal development of 'Delicious' fruiting and vegetative spurs, 2) determine the influence of canopy position and light level on spur development of 'Delicious' and 3) determine in two seasons the relationship of leaf area, light interception, and yield with 'Granny Smith.'

Horticulture/Landscape Architecture Paper no. 89-15. College of Agriculture and Home Economics Research Center, Washington State Univ., Pullman, WA 99164-6414. The support of the Washington Tree Fruit Research Commission is gratefully acknowledged, as is the cooperation of Wells and Wade Fruit Co.

'Dept. of Horticulture, Univ. of Arkansas, Fayetteville, AR 72701.

\section{INFLUENCE OF LIGHT LEVEL ON SPUR DEVELOPMENT}

Seasonal development of leaves of fruiting and vegetative spurs was examined in a commercial orchard in Manson, Wash., with 17-year-old 'Oregon Spur Delicious'/MM.104 trees spaced $3 \times 5.5$ $\mathrm{m}$ in north-south rows. Trees were central leader-trained to a pyramid shape (Heinicke, 1975) and were $\approx 3.5 \mathrm{~m}$ wide at the base and $4 \mathrm{~m}$ tall.

There were three data collection positions near the central leader on each of 24 trees: $1 \mathrm{~m}$ (bottom), $2 \mathrm{~m}$ (middle), and $3 \mathrm{~m}$ (top) above ground level. Spurs were collected within a $50-\mathrm{cm}$ spherical radius of the central leader at each canopy position on 10 dates throughout the 1986 growing season: 23 Apr., 5 May [full bloom (FB)], 12 May $(\mathrm{FB}+7), 19$ May $(\mathrm{FB}+14), 26$ May $(\mathrm{FB}+$ 21), 9 June $(\mathrm{FB}+35)$, 30 June $(\mathrm{FB}+56), 29$ July $(\mathrm{FB}+85)$, 26 Aug. $(\mathrm{FB}+113)$, and at harvest 22 Sept. $(\mathrm{FB}+141)$.

On each date one fruiting spur and one vegetative (nonflowering) spur were collected from each canopy position on each of 24 replicate trees. By collecting only one spur per position per tree per date the impact of spur removal on subsequent development of the remaining spurs was minimized. Leaf number (LNO/SP), area (LA/ $\mathrm{SP} ; \mathrm{cm}^{2}$ ) and dry weight (LDW/SP; $\mathrm{mg}$ ) were determined for each fruiting and vegetative spur. From these values, area per leaf (LA, $\mathrm{cm}^{2}$ ), dry weight per leaf (LDW; mg) and leaf dry weight per unit leaf area $\left(\mathrm{LDW} / \mathrm{LA}, \mathrm{mg} \cdot \mathrm{cm}^{-2}\right)$ were calculated. With fruiting spurs, the primary leaves, those which emerged first in a close spiral directly below the terminal flower cluster, were measured separately from bourse leaves, those which emerged later in the axil of a primary leaf either on short bourse shoots or as a rosette of leaves. With the mature 'Oregon Spur Delicious' trees in this study, bourse shoots rarely were $>5 \mathrm{~cm}$ long and generally were $<1 \mathrm{~cm}$ long and consisted of a rosette of leaves. For the purposes of this study, all bourse leaves, whether on a short shoot or as a rosette, were included in the bourse leaf category. Leaf area was measured with a LI-COR Area Meter (LI-3000/LI-30500; LI-COR, Lincoln, Neb.).

Photosynthetically active radiation (PAR, 400 to $700 \mathrm{~nm}$ ) was measured above each tree and at each canopy position at $1200 \mathrm{HR}$ $\pm 1 \mathrm{~h}$ on the same 10 dates that spurs were collected. Measurements were made with a LI-COR Line Quantum Sensor (LI-191SB) held horizontally in both a north-south and east-west direction with the center $(50 \mathrm{~cm}$ point) of the sensor positioned adjacent to the trunk. The north-south and east-west readings were averaged and compared to the above-canopy readings to calculate percentage of available PAR as a measure of light distribution for the three canopy positions in each tree.

\section{Light distribution}

Available PAR at midday on clear days above the 'Oregon Spur Delicious' tree canopy ranged between 1820 and $1900 \mu \mathrm{mol} \cdot \mathrm{s}^{-1} \cdot \mathrm{m}^{-2}$. At the 1,2 , and $3 \mathrm{~m}$ canopy positions, percent available PAR declined rapidly from mid-April until 9 June (FB + 35) (Fig. 1). At the 1 and $2 \mathrm{~m}$ positions little change in percent available PAR occurred from 9 June to harvest. At each evaluation date percent available PAR for each position was in the sequence $3 \mathrm{~m}>2 \mathrm{~m}$ $>1 \mathrm{~m}$.

\section{Leaves per spur (LNO/SP)}

From 23 Apr. until 26 May $(\mathrm{FB}+21)$, fruiting spurs had more leaves than vegetative spurs, but from 30 June $(\mathrm{FB}+56)$ to 26 Aug. $(\mathrm{FB}+113)$ vegetative spurs averaged about two more leaves per spur than fruiting spurs (Fig. 2A). 


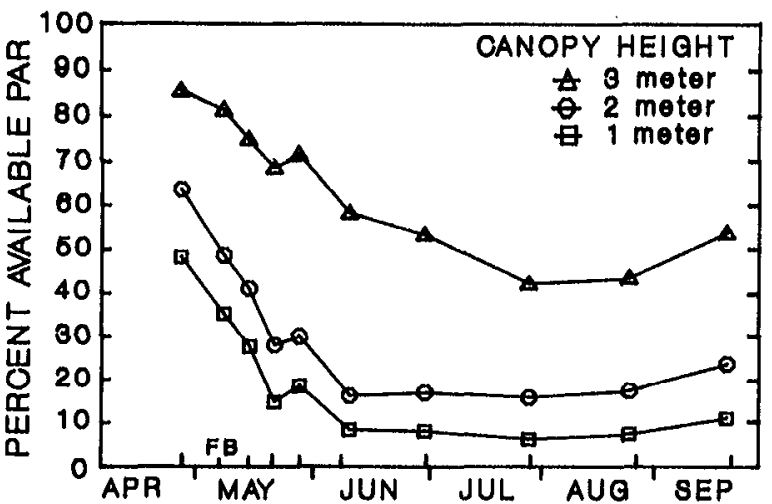

Fig. 1. Percent of available PAR throughout the season in 'Delicious' apple trees at three canopy positions. Full bloom (FB) was 5 May. At each date, percent available PAR was different for each canopy position based on mean separation within dates by Duncan's multiple range test, $\alpha=0.05$. Data are means of 24 observations.

Fruiting spurs had an average of 8.6 primary leaves on 23 Apr., and none developed after that date (Fig. 2A). Primary LNO/SP decreased by abscission to 6.4 by the end of the season. After FB the increase in total leaf number on fruiting spurs was due to a rapid development of bourse leaves between 19 May $(\mathrm{FB}+14)$ and 9 June $(\mathrm{FB}+35)$. Few bourse leaves developed after 9 June,

Fruiting spurs at the $3 \mathrm{~m}$ position had more leaves (total) by midsummer than spurs at the 1 or $2 \mathrm{~m}$ positions (Fig. 2B). This difference, about four leaves per spur, was due entirely to the fact that spurs at the $3 \mathrm{~m}$ position had more bourse leaves than did spurs at the 1 or $2 \mathrm{~m}$ positions (data not shown).

Vegetative spurs at the $3 \mathrm{~m}$ position had more leaves than spurs at the 1 or $2 \mathrm{~m}$ position from 19 May to the end of the season (Fig. $2 \mathrm{C}$ ). By midsummer, spurs at the $3 \mathrm{~m}$ position had $\approx 21$ leaves while spurs at the $1 \mathrm{~m}$ position had just 11 leaves. Leaves at the 1 and $2 \mathrm{~m}$ positions began abscission after late July.

\section{Leaf area per spur (LA/SP)}

Vegetative spurs had greater leaf area than fruiting spurs at each date from FB to harvest (Fig. 3A). Vegetative LA/SP reached a maximum by 30 June $(\mathrm{FB}+56)$, and at that time a vegetative spur had 1.7 times greater leaf area than a fruiting spur. Primary LA/SP increased until 12 May $(\mathrm{FB}+7)$ and did not change thereafter. However, fruit spur leaf area continued to increase until 9 June (FB +35 ) due to an increase in bourse leaf area between 19 May (FB $+14)$ and 9 June $(\mathrm{FB}+35)$.

Canopy position influenced LA/SP for fruiting and vegetative spurs (Fig. 3B). From 9 June $(\mathrm{FB}+35)$ to harvest, vegetative spurs at the $3 \mathrm{~m}$ position had about twice the LA/SP of spurs at the $1 \mathrm{~m}$ position. From 29 July onward, fruiting spur total leaf area at the $3 \mathrm{~m}$ position was greater than that at the $1 \mathrm{~m}$ position, This increase in LA/SP at the $3 \mathrm{~m}$ position was due entirely to an increase in bourse leaf area, as canopy position did not affect primary LA/ SP (Fig. 3C).

\section{Leaf area (LA)}

On the vegetative spurs, LA increased rapidly early in the season but did not increase after 26 May (FB + 21) (Fig. 4). On fruiting spurs, area per bourse leaf increased rapidly from 19 May (FB + 14) to 9 June $(F B+35)$ and thereafter did not change. After 30 June $(\mathrm{FB}+56)$ when leaf development stopped, LA for vegetative spurs was 1.3 times greater than for fruiting spur bourse leaves which, in turn, were 1.5 times greater than fruiting spur primary leaves. Canopy position did not affect LA (data not shown).

\section{Leaf dry weight (LDW)}

Dry weight per leaf followed a pattern of seasonal development similar to LA except that a gradual increase in LDW for bourse leaves of $14 \%$ and for primary leaves of $21 \%$ occurred from 30 June $(\mathrm{FB}+56)$ to the end of the season (data not shown). At the
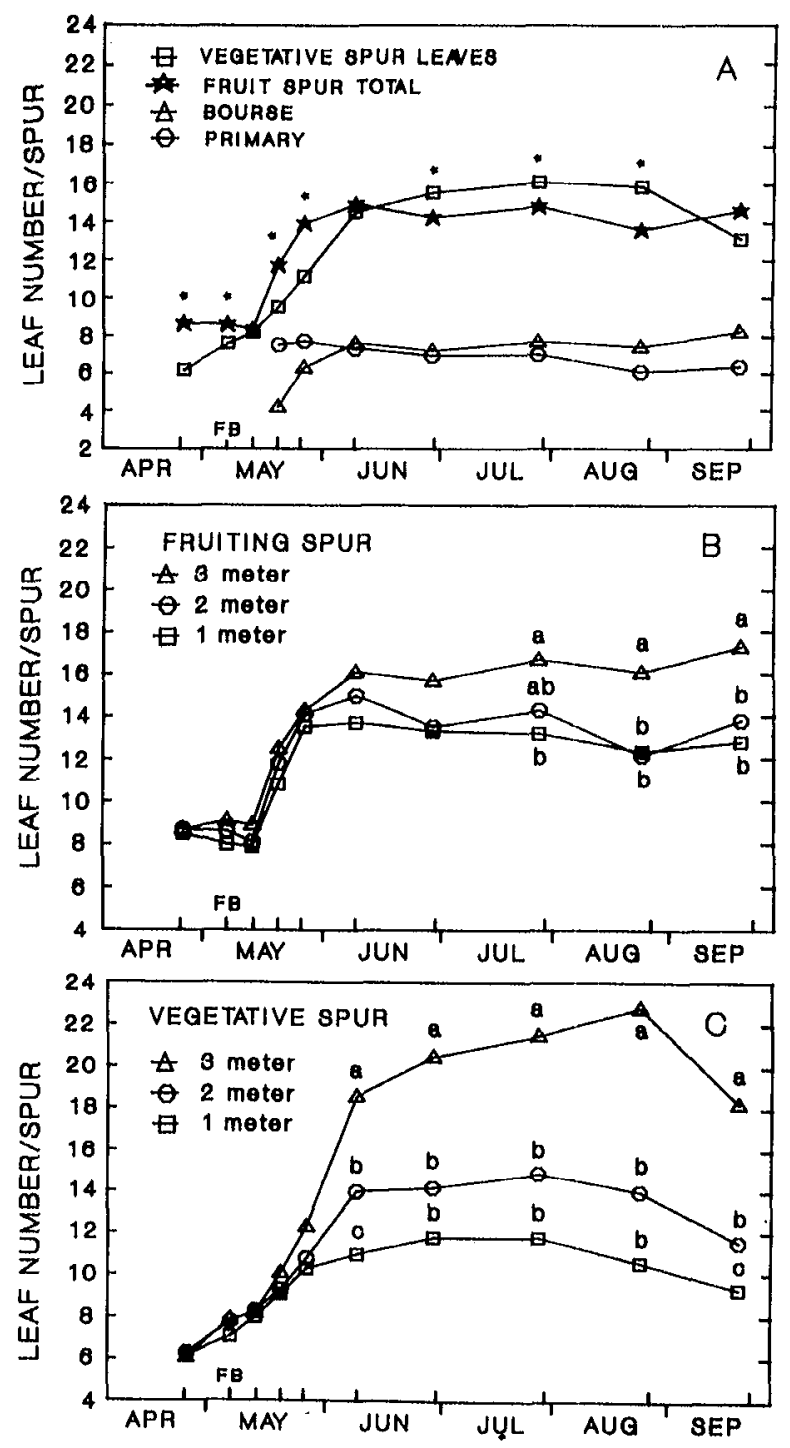

Fig. 2. Effect of spur type and canopy position on 'Oregon Spur Delicious' leaf numbers per spur throughout the season. Full bloom (FB) was 5 May. (A) Leaf number per spur for vegetative spurs and for fruiting spurs including both primary and bourse leaves and the total. * Denotes significant difference between vegetative and total fruiting spur leaf number per spur at each date by $t$ test at $\alpha=0.05$. Data are means of 72 observations. (B) Leaf number per spur for fruit spurs, total of primary and bourse leaves, at three canopy positions. Mean separation within dates by Duncan's multiple range test, $\alpha=0.05$. Data are means of 24 observations. (C) Leaf number per spur for vegetative spurs at three canopy positions. Mean separation within dates by Duncan's multiple range test, $\alpha=0.05$. Data are means of 24 observations.

end of the season, LDW for vegetative spurs and fruiting spur bourse and primary leaves averaged 212,143 , and $102 \mathrm{mg}$, respectively. Canopy position had a major influence on LDW, with leaves at the $3 \mathrm{~m}$ position being heavier than leaves at the $1 \mathrm{~m}$ position (data not shown). This difference was significant $(P=$ $0.05)$ for vegetative, bourse, and primary leaves at each date from 9 June $(\mathrm{FB}+35)$ to the end of the season.

\section{Leaf dry weight per leaf area (LDW/LA)}

Vegetative spur leaves had higher LDW/LA than either primary or bourse fruiting spur leaves from 19 May $(\mathrm{FB}+14)$ to the end of the season (Fig. 5A). LDW/LA declined early in the season with vegetative, primary, and bourse leaves. The early season decline resulted from a very rapid increase in LA (unfolding) during a period when there was a moderate increase in LDW.

With fruiting and vegetative spur leaves, LDW/LA gradually increased from 9 June $(\mathrm{FB}+35)$ to the end of the season. There 

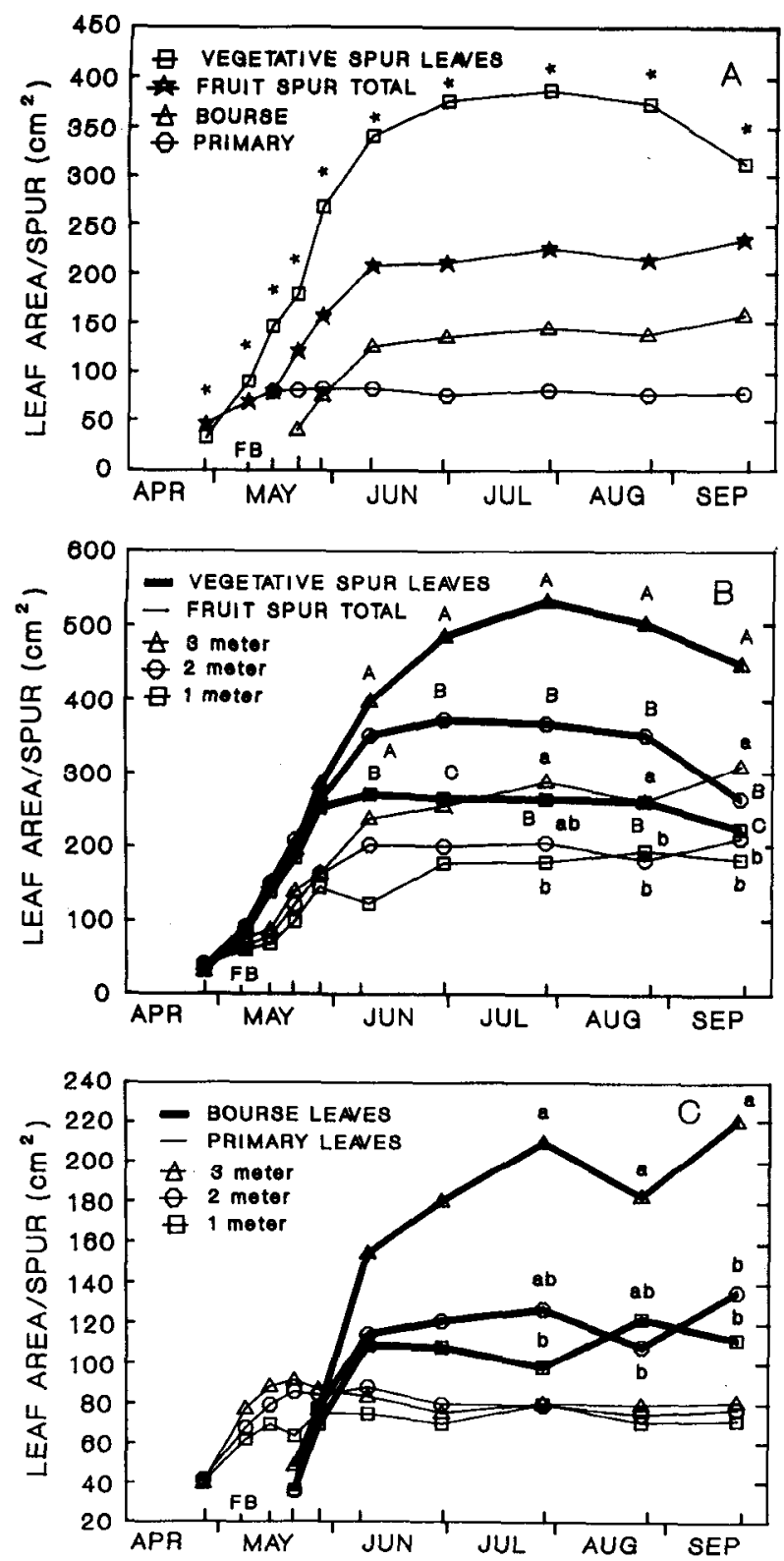

Fig. 3. Effect of spur type and canopy position on 'Oregon Spur Delicious' leaf area per spur throughout the season. Full bloom (FB) was 5 May. (A) Leaf area per spur for vegetative and fruiting spurs including both primary and bourse leaves and the total. * Denotes significant difference between vegetative and total fruit spur leaf area per spur at each date by $t$ test at $\alpha=0.05$. Data are means of 72 observations. (B) Leaf area per spur for fruiting spurs, total of primary and bourse leaves and for vegetative spurs at three canopy positions. Mean separation within dates, upper case letters for vegetative spurs, lower case letters for fruiting spurs, by Duncan's multiple range test, $\alpha=0.05$. Data are means of 24 observations. (C) Leaf area per spur for primary and bourse fruiting spur leaves each at three canopy positions. Mean separation for bourse leaf area within dates by Duncan's multiple range test, $\alpha=0.05$. Data are means of 24 observations.

was no increase in LA after 9 June $(\mathrm{FB}+35)$ (Fig. 4), but LDW continued to increase, resulting in a gradual increase in LDW/LA.

For the entire season after FB, LDW/LA at the $3 \mathrm{~m}$ position was higher than at the $1 \mathrm{~m}$ position for both vegetative (Fig. 5B) and fruiting spur leaves (Fig. 5C). There was a more rapid increase in LDW/LA during the season for leaves at the $3 \mathrm{~m}$ position than at the $1 \mathrm{~m}$ position.

\section{Leaf area and dry weight per spur (LA/SP and LDW/SP)}

The daily increment of LA/SP reached a maximum for vegetative spurs of $\approx 10 \mathrm{~cm}^{2} \cdot \mathrm{day}^{-1}$ between $\mathrm{FB}+14$ and $\mathrm{FB}+21$ days,

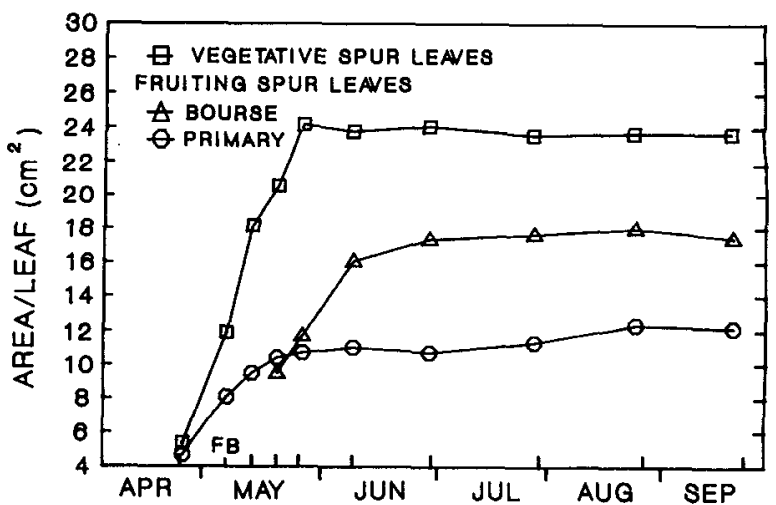

Fig. 4. Effect of vegetative and fruiting spurs (both primary and bourse leaves) on area per leaf of 'Oregon Spur Delicious' throughout the season. Full bloom (FB) was 5 May. At each date from 9 June onward, area per leaf was different for each leaf type based on mean separation by Duncan's multiple range test, $\alpha=0.05$. Data are means of 72 observations.

and for bourse leaves reached a maximum of $\approx 6 \mathrm{~cm}^{2} \cdot$ day $^{-1}$ between $\mathrm{FB}+7$ and $\mathrm{FB}+14$ days (Fig. 6A). A similar pattern occurred for LDW/SP increment with a maximum for vegetative spurs of 90 $\mathrm{mg} \cdot$ day $^{-1}$ between $\mathrm{FB}+14$ and $\mathrm{FB}+21$ days, and for fruiting spur bourse leaves of $40 \mathrm{mg} \cdot \mathrm{day}^{-1}$ between $\mathrm{FB}+7$ and $\mathrm{FB}+14$ days (Fig. 6B). Primary leaves reached their maximum daily increment of LA/SP and LDW/SP before FB.

Canopy position influenced the rate of LA/SP and LDW/SP development. Vegetative and bourse leaves at the $1 \mathrm{~m}$ position stopped area and dry weight growth by 9 June, but at the $3 \mathrm{~m}$ position leaves did not reach zero growth rate until 29 July (Fig. 7 A, B).

Canopy position influenced percent available PAR (Fig. 1) and LNO/SP (Fig. 2), LA/SP (Fig. 3), and LDW/LA (Fig. 5). However, the correlation between percent available PAR and fruiting spur leaf traits differed for each leaf trait (Table 1). LDW/LA had the highest correlation with percent available PAR, followed by LDW and LDW/ SP. The lowest correlations occurred with the traits that did not involve dry weight measurements, that is, LA/SP, LNO/SP, and LA. The relationships of percent available PAR with spur leaf traits were similar at midseason (30 June) and at harvest (22 Sept.) in an earlier study (Barritt et al., 1987).

Light levels within an apple tree decline rapidly in the spring as leaf canopy develops (Lakso, 1980; Marini and Barden, 1982; Porpiglia and Barden, 1980), and light levels within the canopy decline as the distance from the periphery of the canopy increases (Barritt et al., 1987; Ferree, 1980; Jackson, 1980; Morgan et al., 1984; Tustin et al., 1988; Wertheim et al., 1986). The present study with large 'Delicious' trees confirms previous observations and shows light levels considerably $<30 \%$ exist in tree canopies for $>4$ months of the growing season beginning shortly after bloom. When light levels fall below $30 \%$, there is a significant reduction in flower bud development, fruit set, fruit size, fruit quality, and productivity (Jackson, 1980).

Seasonal development of apple spurs has been studied with 'Empire' (Lakso, 1984) and with 'McIntosh' (Cain, 1973; Forshey et al., 1987). Lakso (1984) found that maximum LA/SP was $\approx 9.5 \mathrm{~cm}^{2}$ for vegetative spurs and that vegetative spurs had $\approx 1.4$ times the leaf area of fruiting spurs. In the present study with 'Delicious', maximum LA/SP was $\approx 375 \mathrm{~cm}^{2}$ for vegetative spurs, and vegetative spurs had $\approx 1.8$ times the leaf area of fruiting spurs. The low LA/SP for 'Empire' in New York was due in part to a very dry early season, which stopped spur leaf growth at about FB +20 days (1 June). With 'Delicious' under irrigation in Washington, growth continued beyond $\mathrm{FB}+35$ days (9 June), and with vegetative spurs at the $3 \mathrm{~m}$ position, LA/SP continued to increase until FB +85 (29 July). Forshey et al. (1987) found that 'McIntosh tree spur leaf area (vegetative and fruiting spurs were combined and bourse shoot leaves were not included) did not increase appreciably after FB + 35 ( 2 June). The present study and the studies of Barritt and Schonberg (1990), Lakso (1984), and Forshey et al. (1987) support Cain's (1973) general model for spur leaf area development, 

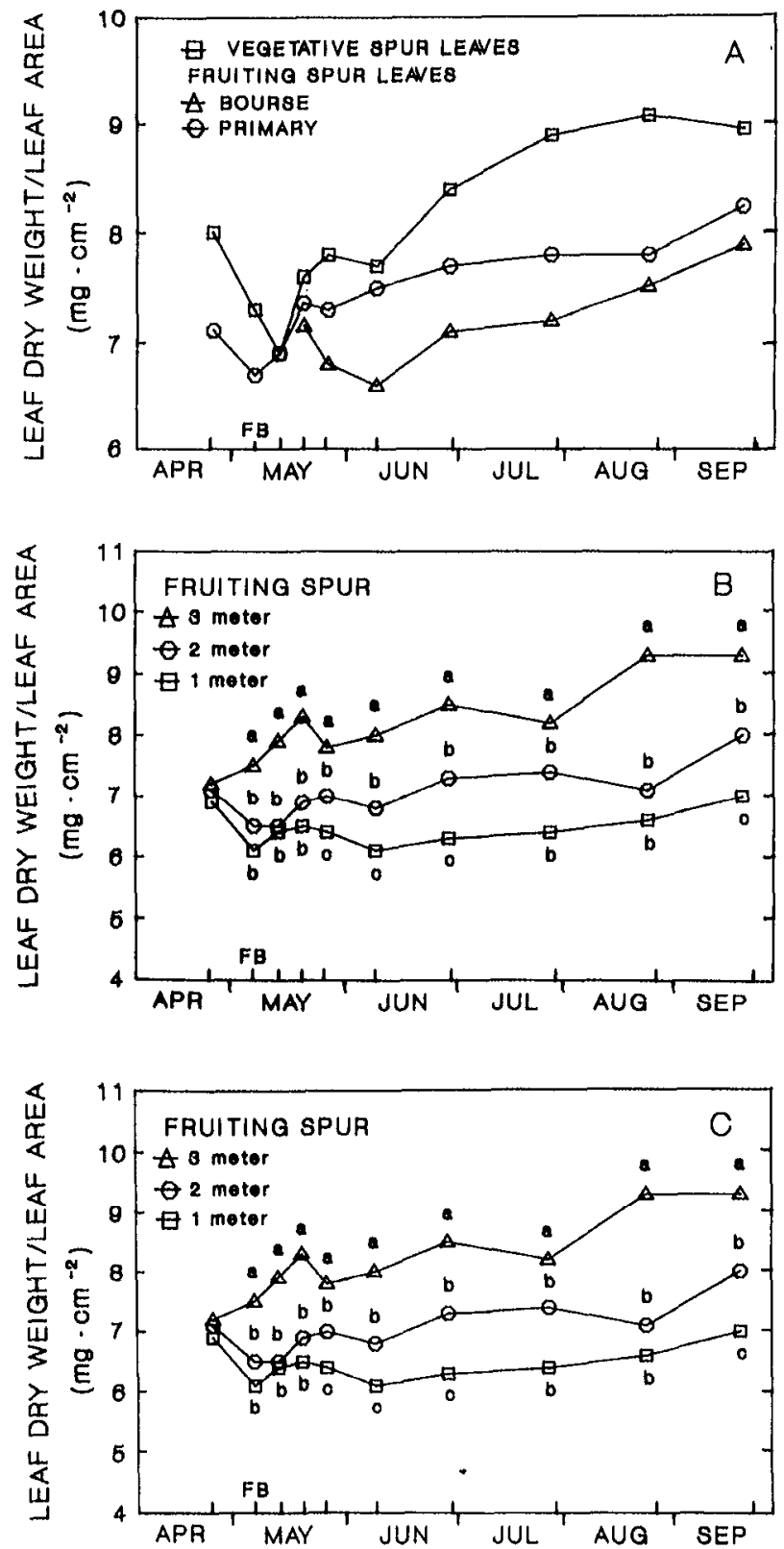

Fig. 5. Effect of spur type and canopy position on 'Oregon Spur Delicious' leaf dry weight per leaf area throughout the season. Full bloom (FB) was 5 May. (A) Leaf dry weight per leaf area for vegetative and fruiting spur leaves (both primary and bourse). At each date from June 9 onward, all leaf categories were different from each other based on mean separation by Duncan's multiple range test, $a=0.05$. Data are means of $72 \mathrm{ob}-$ servations. (B) Leaf dry weight per leaf area for vegetative spur leaves at three canopy positions. Mean separation within dates by Duncan's multiple range test, $a=0.05$. Data are means of 24 observations. (C) Leaf dry weight per leaf area for fruiting spur leaves, primary and bourse leaves combined, at three canopy positions. Mean separation within dates by Duncan's multiple range test, $a=0.05$. Data are means of 24 observations.

although the precise time when spur leaf area is complete varies with spur type, cultivar, season, and location.

Considerable variability in LA/SP has been reported. Maximum LA/SP at midseason for 'Delicious' in the present study was generally greater than for earlier studies with 'Delicious' (Ferree and Schmid, 1988; Westwood and Zielinski, 1966), 'Golden Delicious' (Ferree and Schmid, 1988), and 'Empire' (Lakso, 1984). In these studies, LA was smaller and LNO/SP was usually lower, perhaps because bourse leaves were not always included as part of fruiting spurs. The greater LA/SP with both fruiting and vegetative spurs in the present study than in an earlier study with 'Delicious' (Barritt
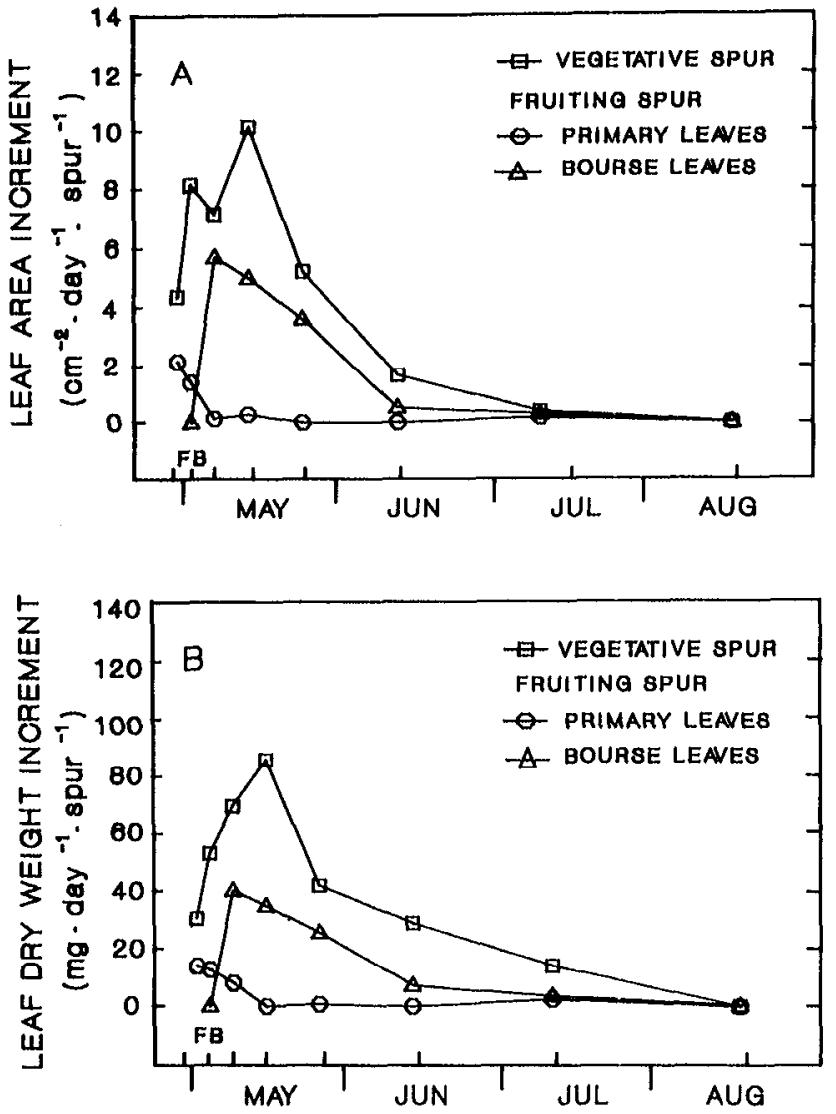

Fig. 6. Leaf area (A) and dry weight (B) daily increment per spur for vegetative and fruiting spurs of 'Oregon Spur Delicious'. Data are means of 24 observations.

et al., 1987) was due to greater LNO/SP and LA. Leaf area of vegetative spurs of 'Starkrimson Delicious' in Ohio ranged from 62 to $98 \mathrm{~cm}^{2}$, depending on canopy position, while in the present study with 'Oregon Spur Delicious', it ranged from 250 to $500 \mathrm{~cm}^{2}$, also depending on canopy position. Leaf area per fruiting spur, when primary and bourse shoot leaves were included, with 'McIntosh' (Forshey et al., 1987) and 'Delicious' (Rom and Ferree, 1984b) was generally similar to the present study. Apparently, at least canopy position, light level (discussed above), cultivar (Rom and Ferree, 1984c), and pruning (Ferree and Forshey, 1988; Lakso, 1984) contribute to variability in LA/SP. However, additional studies are required to clarify the influence of these and other factors on LA/SP.

Canopy position, and thus light level, had a direct effect on seasonal development and eventual quality of both vegetative and fruiting spurs. Rom and Ferree (1984b) with greenhouse-grown 'Delicious' trees found that shade from before bloom until fruit set reduced LNO/SP, LA/SP, and LDW/LA with primary and bourse leaves. The reduction in LA/SP from the top to bottom canopy position confirms similar observations with large 'Delicious' trees (Barritt et al., 1987; Ferree and Forshey, 1988). The reduction in LA/SP at the $1 \mathrm{~m}$ canopy position compared with the $3 \mathrm{~m}$ position in the present study was due to a reduction in the LNO/SP, but not a reduction in LA. Reductions in LDW/LA in the present study in the interior and shaded portions of the canopy confirmed earlier reports with shoot and spur leaves of several cultivars (Barritt et al. 1987; Ferree and Forshey, 1988; Maggs, 1960; Marini and Barden, 1981, 1982; Porpiglia and Barden, 1980). The gradual increase in LDW/LA toward the end of the season in the present study also confirms earlier findings (Brown et al., 1985; Marini and Barden, 1981; Porpiglia and Barden, 1980). The early season decline in LDW/LA has not been reported previously.

The quality of a fruiting spur is determined by the extent of bourse leaf development. Bourse leaf development was found to be critical for fruit set, large fruit size, and fruit $\mathrm{Ca}$ concentration (Abbott, 

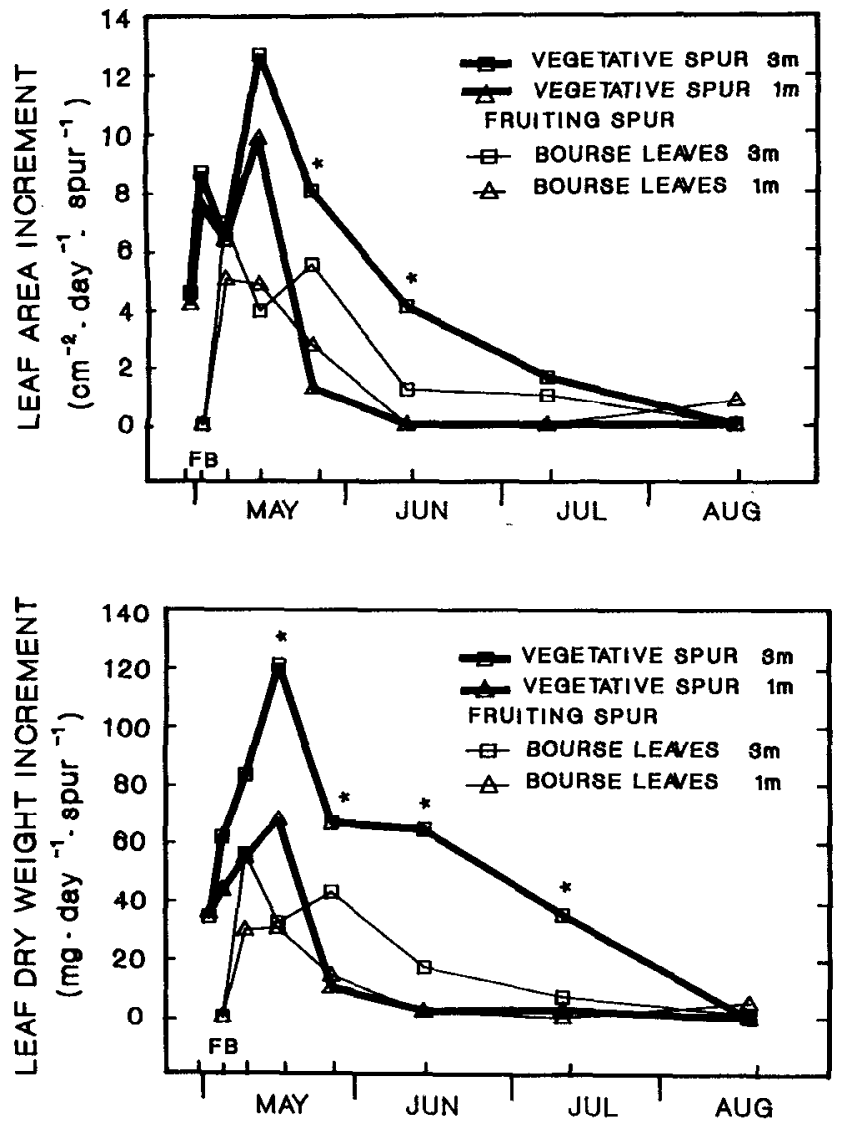

Fig. 7. Leaf area (A) and dry weight (B) daily increment per spur for vegetative and fruiting spur bourse leaves at the $3 \mathrm{~m}$ and $1 \mathrm{~m}$ canopy positions. * Indicates that for vegetative leaves within dates, leaf area and leaf dry weight increments were different for the $3 \mathrm{~m}$ and $1 \mathrm{~m}$ positions based on $t$ test, $\alpha=0.05$. Data are means of 24 observations.

1960; Ferree and Palmer, 1982). Bourse leaf area per spur was substantially greater in the top and well-illuminated portion of the canopy ( $3 \mathrm{~m}$ position) than in the lower canopy positions.

Fruit size is influenced by both spur leaf area and shoot leaf area. Removal of spur leaves 90 or 120 days after full bloom did not influence fruit size, but removal 60 days after full bloom resulted in smaller fruit than leaf removal at 120 days (Rom and Ferree, 1984a). Early primary and bourse leaf removal did reduce fruit size (Ferree and Palmer, 1982). In the present study, canopy position greatly influenced fruiting spur leaf area to the extent bourse leaf development was reduced. End-of-season LDW/LA and LDW/SP have been correlated with fruit size, but LA/SP was not (Barritt et al., 1987). Although shoot leaf area plays a major role in determining final fruit size, spur quality is also important and can be limiting by exposure to low levels of sunlight.

The rate of total tree leaf area development with 'Empire' showed two peaks, one just before bloom and a second peak $\approx 2$ weeks after bloom (Lakso, 1984). It may be that the first peak was primarily the rate of spur leaf development and the second peak the rate of shoot leaf development. In the present study the greatest daily LA/SP and LDW/SP increment for vegetative spurs occurred between $\mathrm{FB}+14$ and $\mathrm{FB}+21$ and for bourse leaves the greatest growth increment occurred $\approx 1$ week earlier. The rate of leaf area development was declining before bloom for primary leaves. Vegetative spur leaves continued to grow later than fruiting spur leaves. The rate of leaf area development was greater and extended longer for well-illuminated spurs at the $3 \mathrm{~m}$ position than at the more shaded $1 \mathrm{~m}$ position. Maggs (1960) found the rate of leaf development in full sunlight was greater than in deep shade ( $24 \%$ full sunlight)
Table 1. Correlation coefficients (r) for the relationships of percent available PAR with fruiting spur leaf characteristics of 'Delicious' apple. Data for only two sampling dates are presented.

\begin{tabular}{|c|c|c|c|c|c|c|}
\hline \multirow[b]{2}{*}{ Spur leaf type } & \multicolumn{6}{|c|}{ Leaf characteristics ${ }^{2, y}$} \\
\hline & LDW/LA & LDW & LDW/SP & LA/SP & LNO/SP & LAA \\
\hline & \multicolumn{6}{|c|}{30 June, $F B+56$ days } \\
\hline Primary leaves & $0.68 * * *$ & $0.35^{* *}$ & $0.25^{*}$ & 0.03 & 0.03 & 0.04 \\
\hline Bourse leaves & $0.70^{* * *}$ & $0.53^{* * *}$ & $0.41 * * *$ & $0.31 * *$ & $0.29^{*}$ & 0.23 \\
\hline \multirow[t]{2}{*}{ All leaves } & $0.71^{* * *}$ & $0.49^{* * *}$ & $0.40^{* * *}$ & $0.28^{*}$ & $0.27^{*}$ & 0.20 \\
\hline & \multicolumn{6}{|c|}{22 Sept., $F B+141$ days } \\
\hline Primary leaves & $0.48^{* * *}$ & $0.29^{*}$ & $0.31^{* *}$ & 0.01 & 0.01 & 0.03 \\
\hline Bourse leaves & $0.53^{* * *}$ & $0.36^{* *}$ & $0.32 * *$ & $0.25^{*}$ & $0.26^{*}$ & 0.13 \\
\hline All leaves & $0.55^{* * *}$ & $0.36^{* *}$ & $0.34^{* *}$ & $0.26^{*}$ & $0.26^{*}$ & 0.15 \\
\hline
\end{tabular}

${ }^{z_{n}}=72$.

'LDW/LA, leaf dry weight/leaf area; LDW, dry weight/leaf; LDW/SP, leaf dry weight/spur; LA/SP, leaf area/spur, LNO/SP, leaf number/spur; LA, area/leaf.

*,**,***Significant at $P=0.05,0.01$, or 0.001 , respectively.

\section{CANOPY DEVELOPMENT, LIGHT INTERCEPTION, AND YIELD}

From the above discussion, it is apparent that high quality spurs with large leaf area are located only in areas of the canopy that receive high light levels. The shape of the tree and the configuration of limbs, the orchard training system, not only influence the distribution of light within the canopy and, therefore, spur quality but also influence the percentage of above-tree light that is intercepted by the orchard canopy. To examine the relationship of canopy development, light interception, and fruit production, a 'Granny Smith orchard systems trial was established in 1985 near Wenatchee, Wash. The orchard training systems were: 1) free-standing central leader with Mark and M.26 EMLA rootstocks spaced at $2.25 \times 5 \mathrm{~m}(880$ trees/ha); 2) vertical-axis with Mark, M.26 EMLA, and M.9 EMLA rootstocks at $1.75 \times 4.5 \mathrm{~m}(1270$ trees/ha); and 3) slender spindle with M.26 EMLA and M.9 EMLA at $1.5 \times 4.0 \mathrm{~m}$ (1667 trees/ ha). Rows were in a north-south direction. A 10.5-m-long plot of each system/rootstock combination with five to seven trees was replicated four times in a randomized complete block design. Orchard systems were separated by double guard rows of 'Golden Delicious' trained to the same systems. In 1987 (3rd year) and 1988, yield $\left(\mathrm{t} \cdot \mathrm{ha}^{-1}\right)$, percent light interception, and leaf area/ha were determined. Total leaf area per tree was determined in mid-August from one tree in each block for each training system/rootstock combination. Every 50th spur leaf and every 25 th shoot leaf were collected and their leaf area determined to estimate total leaf area per tree. $($ Leaf area/ha) $/ 10,000=$ orchard leaf area index $(\mathrm{LAI})$. On clear days, 5 Aug. 1987, and 4 Aug. 1988, light interception (percentage of the above-tree PAR striking the tree canopy) was estimated at midday for one tree of each training system/rootstock combination in each block using a LI-COR Line Quantum Sensor. Below-canopy light measurements with the meter-long sensor were taken at meter intervals on two east-west transects from mid-alley to mid-alley. One transect was adjacent to the trunk and the other was one-half the distance to the adjacent tree in the row. The midalley to mid-alley distance varied from 4 to $5 \mathrm{~m}$ depending on the orchard system. For each tree, two above-canopy and eight to 10 below-canopy measurements were taken. These readings were used to calculate percent light interception as follows: (1 - below-canopy mean/above-canopy mean) $\times 100$.

In the 'Granny Smith' orchard systems trial, typical midday abovecanopy PAR in Aug. was 1700 to $1850 \mu \mathrm{mol} \cdot \mathrm{s}^{-1} \cdot \mathrm{m}^{-2}$. Percent light interception varied from $13 \%$ for free-standing central leader trees the 3rd year to $39 \%$ for slender spindle trees the 4th year. Average light interception over all orchard systems was $22 \%$ the 3 rd year and $27 \%$ the 4 th year. Spur leaf area/ha increased from year 3 to year 4 by $89 \%$ while shoot leaf area/ha increased by just $15 \%$. Mean leaf area/ha (spur and shoot leaves) for all orchard 
systems was $5765 \mathrm{~m}^{2}$ the $3 \mathrm{rd}$ year and $8341 \mathrm{~m}^{2}$ the 4 th year, a $45 \%$ increase. For all orchard systems, total leaf area/ha from spur leaves increased from $40 \%$ the 3rd year to $52 \%$ the 4 th year. During two seasons, percent light interception was positively correlated with leaf area/ha ,r=0.933 (Fig. 8). Yield/ha was correlated with both percent light interception,$r=0.886$ and with leaf area/ha $r=$ 0.834 .

Jackson (1980) suggested that dry matter and economic yields of apple orchards, like many other crops, appear to be directly related to the level of light interception. In the present study with 3- and 4-year-old trees, both light interception and leaf area/ha were correlated with yield (t.ha' ${ }^{-1}$ ). Recent studies by Barritt (1989), Wagenmakers and Callesen (1989), Robinson and Lakso (1989), and Wertheim (1986) reported that yield/ha was related to light interception. In an orchard systems trial with 'Golden Delicious', 6thyear yield $\left(\mathrm{kg} \cdot \mathrm{ha}^{-1}\right)$ was not closely associated with leaf area/ha (Ferree, 1980). Slender spindle trees had the highest production and leaf area/ha, while trellised trees and pyramid hedgerow trees had fairly similar leaf area/ha, but trellised trees had twice the production of the pyramid hedgerow system. The relationship of light interception and leaf area/ha (LAI) in the present study with young trees confirms field observations (Palmer and Jackson, 1977) and
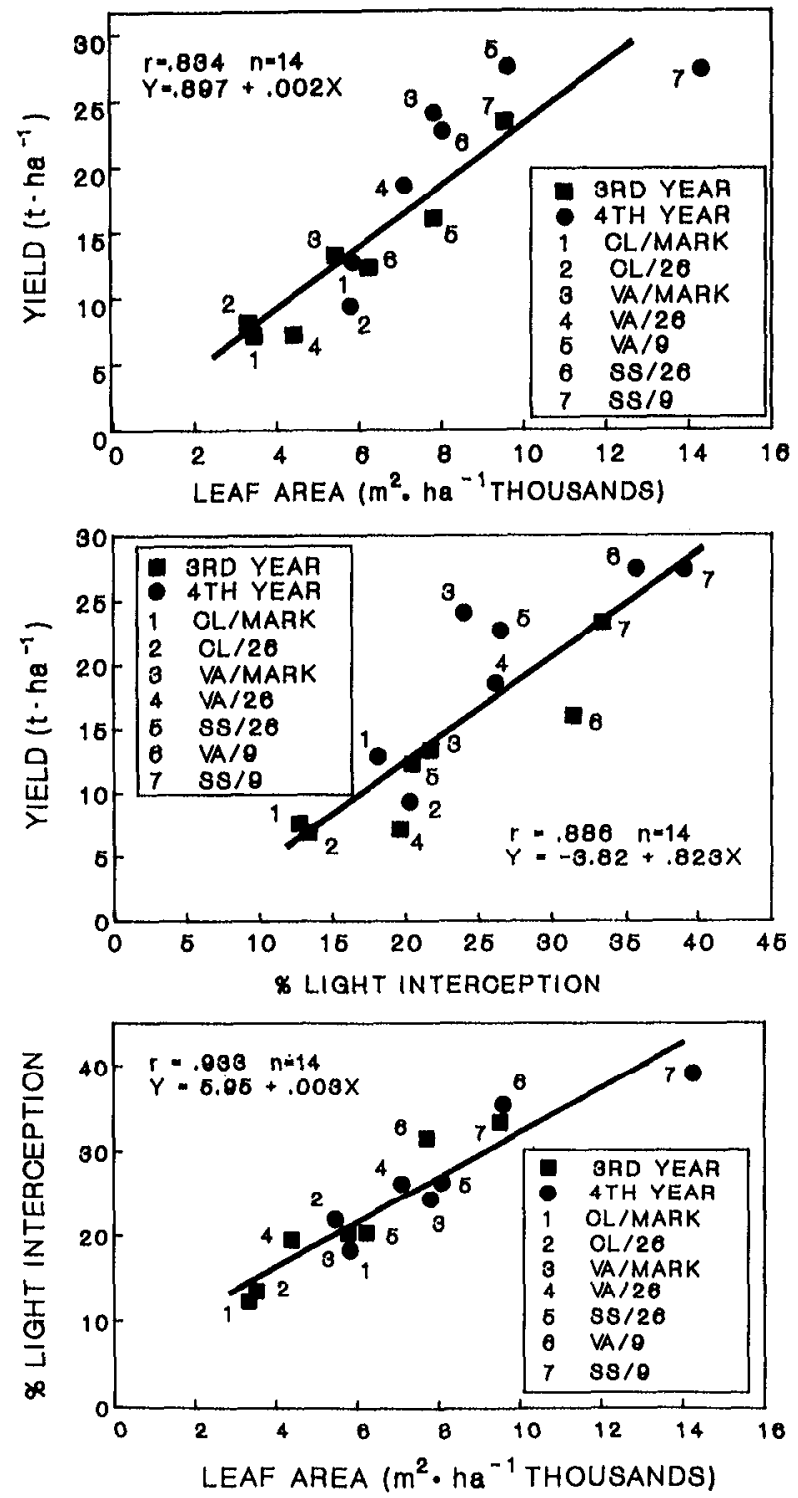

Fig. 8. Relationships among light interception, leaf area/ha and fruit production $\left(\mathrm{t} \cdot \mathrm{ha}^{-1}\right)$ for 3rd and 4th year 'Granny Smith' trees trained to the free-standing central leader (CL), the vertical-axis (VA), and the slender spindle (SS) orchard systems on Mark, M.26 EMLA, and M.9 EMLA rootstocks. computer model expectations (Palmer, 1981). In the future, data from the early, mid-, and late years of an orchard should enable researchers to characterize and model the critical relationships of light interception, leaf area/ha, and production for the useful life of an orchard.

\section{SUMMARY}

With spur-type 'Delicious', spur leaf area developed rapidly in the spring and generally was complete in early June (FB+ 35). Fruiting spur primary leaves completed their development before bourse leaves and vegetative spur leaves. As leaf area developed in the spring, available PAR declined rapidly, particularly inside the canopy. Less than 20\% PAR was available from early June to the end of the season at low inside canopy positions. With fruiting spurs, canopy position and, thus, available PAR dramatically influenced LDW/LA, LDW, and LDW/SP; higher available PAR resulted in higher leaf weight parameters, but canopy position had less influence on LA, LA/SP, and LNO/SP.

With young 'Granny Smith' trees trained to several orchard systems at several tree densities and on several rootstocks, light interception the 4 th year varied from $10 \%$ to $40 \%$. Light interception and leaf area/ha were highly correlated. Yield $\left(\mathrm{t} \cdot \mathrm{ha}^{-1}\right)$ over two seasons was positively correlated with leaf area/ha and with percent light interception.

\section{Literature Cited}

Abbott, D.L. 1960. The bourse shoot as a factor in the growth of apple fruits. Ann. Applied Biol. 48:434-438.

Barritt, B.H. 1989. Influence of orchard system on canopy development, light interception and production of third-year Granny Smith apple trees. Acta Hort. 243:121-130.

Barritt, B.H. and B.J. Schonberg. 1990. Cultivar and canopy position effects on seasonal development of vegetative spurs of apple. HortScience 25:628-631.

Barritt, B.H., C.R. Rom, K.R. Guelich, S.R. Drake, and M.A. Dilley. 1987. Canopy position and light effects on spur, leaf, and fruit characteristics of 'Delicious' apple. HortScience 22:402-405.

Brown, C.S., E. Young, and D.M. Pharr. 1985. Rootstock and scion effects on carbon partitioning in apple leaves. J. Amer. Soc. Hort. Sci. 110:701705 .

Cain, J.C. 1973. Foliage canopy development of 'McIntosh' apple hedgerows in relation to mechanical pruning, the interception of solar radiation, and fruiting. J. Amer. Soc. Hort. Sci. 98:357-360.

Curry, E.A. and M.W. Williams. 1983. Promalin or $\mathrm{GA}_{3}$ increase pedicel and fruit length and leaf size of Delicious apples treated with paclobutra201. HortScience 18:214-215.

Ferree, D.C. 1980. Canopy development and yield efficiency of 'Golden Delicious' apple trees in four orchard management systems. J. Amer. Soc. Hort. Sci. 105:376-380.

Ferree, D.C. 1989. Influence of orchard management system on spur quality, light, and fruit within the canopy of 'Golden Delicious' apple trees. J. Amer. Soc. Hort. Sci. 114:869-875.

Ferree, D.C. and C.G. Forshey. 1988. Influence of pruning and urea sprays on growth and fruiting of spur-bound 'Delicious' apple trees. J. Amer. Soc. Hort. Sci. 113:699-703.

Ferree, D.C. and J.W. Palmer. 1982. Effect of spur defoliation and ringing during bloom on fruiting, fruit mineral level, and net photosynthesis of 'Golden Delicious' apple. J. Amer. Soc. Hort. Sci. 107:1182-1186.

Ferree, D.C. and J.C. Schmid. 1988. Influence of growth regulators on apple spur quality and tree performance. Fruit Crops 1987: A Summary of Res. Ohio Agr. Res. Dev. Ctr. Res. Circ. 295:1-6.

Forshey, C.G. and D.C. Elfving. 1989. The relationship between vegetative growth and fruiting in apple trees, Hort. Rev. 11:229-287.

Forshey, C.G., R.W. Weires, and J.R. VanKirk. 1987. Seasonal development of the leaf canopy of 'Macspur McIntosh' apple trees, HortScience 22:881-883.

Heinicke, D.R. 1975. High-density apple orchards-planning, training, and pruning. U.S. Dept. Agr. Hdbk. 458.

Jackson, J.E. 1978. Utilization of light resources by HDP systems. Acta Hort. 65:61-70.

Jackson, J.E. 1980. Light interception and utilization by orchard systems. Hort. Rev. 2:208-267.

Jackson, J.E. and J.W. Palmer. 1974. Light interception and distribution in relation to intensive orchard systems. Proc. 19th Intl. Hort. Cong. Warsaw 1B:539. 
Lakso, A.N. 1980. Correlations of fisheye photography to canopy structure, light climate, and biological response to light in apple trees. J. Amer. Soc. Hort. Sci. 105:43-46.

Lakso, A.N. 1984. Leaf area development patterns in young pruned and unpruned apple trees. J. Amer. Soc. Hort. Sci. 109:861-865.

Maggs, D.H. 1960. The stability of the growth pattern of young apple-trees under four levels of illumination. Ann. Bot. 24:434-450.

Marini, R.P. and J.A. Barden. 1981. Seasonal correlations of specific leaf weight to net photosynthesis and dark respiration of apple leaves. Photosynthesis Res. 2:251-258.

Marini, R.P. and J.A. Barden. 1982. Light penetration on overcast and clear days, and specific leaf weight in apple trees as affected by summer or dormant pruning. J. Amer. Soc. Hort: Sci. 107:39-43.

Morgan, DC., C.J. Stanley, R. Volz, and I.J. Warrington. 1984. Summer pruning of 'Gala' apple: the relationships between pruning time, radiation penetration, and fruit quality. J. Amer. Soc. Hort. Sci. 109:637-642.

Oh, S.D., D.G. Choi, and J.M. Park. 1987. Effects of spur leaves on spur bud development and flower bud formation in apple tree. J. Korean Hort. Soc. 28:37-44

Palmer, J.W. 1981. Computed effects of spacing on light interception and distribution within hedgerow trees in relation to productivity. Acta Hort. 114:80-88

Palmer, J.W. and J.E. Jackson. 1977. Seasonal light interception and canopy development in hedgerow and bed system apple orchards. J. Applied Ecol. 14:539-549.

Porpiglia, P.J. and J.A. Barden. 1980. Seasonal trends in net photosynthetic potential, dark respiration, and specific leaf weight of apple leaves as affected by canopy position. J. Amer. Soc. Hort. Sci. 105:920-923.

Robinson, T.L. and A.N. Lakso. 1989. Light interception yield and fruit quality of Empire and Delicious apple trees grown in four orchard systems. Acta Hort. 243:175-184.

Rom, C.R. and D.C. Ferree. 1984a. The role of spur leaves. Compact Fruit Tree 17:152-155.

Rom, C.R. and D.C. Ferree. 1984b. The influence of light environment early in the season on bloom, fruit development, and return bloom of 'Starkrimson' Red Delicious grown in a greenhouse. Fruit Crops 1984: A Summary of Res. Ohio Agr. Res. Dev. Ctr. Res. Circ. 203:9-16.

Rom, C.R. and D.C. Ferree. 1984c. Spur leaf characteristics of nine apple cultivars. Fruit Var. J. 38:2-5.

Tustin, D.S., P.M. Hirst, and I.J. Warrington. 1988. Influence of orientation and position of fruiting laterals on canopy light penetration, yield, and fruit quality of 'Granny Smith' apples. J. Amer. Soc. Hort. Sci. 113:693-699.

Wagenmakers, P.S. and O. Callesen. 1989. Influence of light interception on apple yield and fruit quality related to arrangement and tree height. Acta Hort. 243:149-158.

Wertheim, S.J., A. de Jager, and M.J.J.P. Duyzens. 1986. Comparison of single-row and multi-row planting systems with apple, with regard to productivity, fruit size and color, and light conditions. Acta Hort. 160:243258.

Westwood, M.N. and Q.B. Zielinski. 1966. Comparative growth habit and leaf composition of a compact mutant and standard Delicious apple. Proc. Amer. Soc. Hort. Sci. 88:9-13. 